Article

\title{
Do Local Food Networks Foster Socio-Ecological Transitions towards Food Sovereignty? Learning from Real Place Experiences
}

\section{Juliana Lutz ${ }^{1, *}$ and Judith Schachinger ${ }^{2}$}

1 Institute of Social Ecology Vienna (SEC), Alpen-Adria Universitaet (AAU), Schottenfeldgasse 29, Vienna 1070, Austria

2 SpeiseLokal, Hof 3, Maria Anzbach 3034, Austria; E-Mail: judith@speiselokal.at

* Author to whom correspondence should be addressed; E-Mail: Julia.Lutz@aau.at; Tel./Fax: +43-1-522-4000-345.

Received: 29 August 2013; in revised form: 21 October 2013 / Accepted: 31 October 2013 / Published: 7 November 2013

\begin{abstract}
Drawing on transition theory, we conceptualize local food networks as innovations that initially function and develop in local niches within a given food regime. As niche-innovations local food networks induce socio-ecological changes on the local level and they have the potential to foster wider transformations of the dominant food regime. Many local food networks adopt the concept of food sovereignty as a kind of "leitmotif". At the core of this concept lies the question of how to create an agro-food system that, (i) allows for democratic participation and civic engagement in food production, and (ii) sets up new relationships that avoid social inequity and the exploitation of both humans and nature. In this paper we shed light on how the Austrian local food network "SpeiseLokal" addresses the challenge of operationalizing the concept of food sovereignty. The case study captures the strategies which local food networks embark on and depicts the difficulties they encounter. The paper aims to identify critical points of intersection that either strengthen or constrain local food networks from becoming established, operating, and up-scaling in the ways they wish; that is, in accordance with the principles and aims of food sovereignty, while avoiding a later assimilation into the dominant food regime.
\end{abstract}

Keywords: local food networks; food sovereignty; sustainable transitions; niche innovation; food regime 


\section{Introduction}

It has often been stated that our food system is ecologically, economically, and socially unsustainable [1-4]. Agriculture in the global North is highly dependent on fossil energy and accounts for about $40 \%$ of all $\mathrm{CO}_{2}$ emissions. It consumes more energy than it provides and reduces soil fertility and bio-diversity. Our food transportation system and the processing, packaging, and distribution of food also consume a high amount of (fossil) energy, further increasing $\mathrm{CO}_{2}$ emissions. In addition, our food system is rooted in social inequality, causing hunger in the global South, which has become highly dependent on food supplied by the global North [5-7]. The prices for agricultural raw products - and with this, the rate of agricultural wages - are low and determined by the dynamics of the global market [8-11]. Food has become another commodity, and traded just like computers or cars. In effect food production and food supply chains are dominated by big retailers, and farmers and consumers have widely lost control of them. Finally, industrialized production has made food increasingly unhealthy, causing disease and, both, overweight and malnourished people [6].

Organic agriculture and the organic movement have long been regarded as the way out of our (coming) food crises - using less energy, engendering long-lasting soil fertility, and providing a better income for small farmers [12-14]. Given the conventionalization of organic agriculture [15-18], it becomes evident that organic or other "environmentally friendly" production methods are insufficient to providing a sustainable food system [19]. Rather, it is argued, food should not only be environmentally friendly but locally and fairly produced, sourced, distributed, and consumed [20,21]. This would lead to significant socio-economic changes that would allow for civic empowerment and it would lead to a seasonal, low meat diet [22] due to the limited local availability of arable land. It would mean to reconnect "what the dominant food regime separates and replaces with money and finance: crops from animals, eaters from growers, rich from poor, farm from forest, watersheds, carbon cycles, and all of these from the ever-flowing energy of [the] sun" [23].

However, a similar tension to the one that shaped the organic movement and finally led to its conventionalism seems to be shaping the local food movement. This is the tension between capitalist agro-food corporations and grass-roots movements with their emergent food-niches. On the one hand, one can observe a shift towards "green capitalism" [9] in the sense that supermarket-led agro-food capitals create "localized" foods [24] or "food from somewhere" [25]. These localized foods are not necessarily produced close to where they are sold and consumed; rather they provide "flexible and traceable supply chains based on standard norms of quality" [26]. These quality standards are defined by the supermarkets themselves as well as by national and international institutions, such as the global GAP audit system - an association of supermarket-chains, auditing and marketing institutions — or the Codex Alimentarius that comprises international food standards defined by FAO (Food and Agriculture Organization of the United Nations) and WHO (World Health Organization). Thus, "localized foods" or "foods from somewhere" are still subject to the inherent dynamics and power-relations of the dominant food regime [25] and mitigate civic engagement. On the other hand, social movements such as the Slow Food and Via Campesina movement are introducing and promoting new ways of organizing local food supply chains by adhering to the concept of food sovereignty. In that context, food sovereignty is a political project that can "broadly (be) defined as the right of nations and peoples to control their own food system, including their own markets, production 
modes, food cultures and environments" [27]. Food, it is argued, should be produced for people and not for (international) markets dominated by transnational corporations. With this in mind, food sovereignty focuses on the people who produce, distribute, and consume food. It promotes small farms and peasants who apply organic or agro-ecological farming methods as well as small-scaled systems of food distribution. The idea is to establish and strengthen national, regional and local food networks that provide healthy, affordable, ecologically sound, and culturally diverse foods. This should be done in ways that allow for democratic participation, social equity, cultural and natural diversity, and a more resilient and regenerative environment where renewable energies are used. Such food networks, it is suggested, strengthen the inherent socio-cultural and environmental characteristics of the communities involved [28,29] and help to sustain the livelihoods of small and medium-sized farms that host a considerable portion of the world's population, thereby reducing pressure on overpopulated cities [30]. As Campbell [25] argues, the size, flexibility, and socio-ecological variety of local food networks provide the potential to establish a resilient and more responsive food system. In its report of 2009 the International Assessment of Agricultural Knowledge, Science and Technology of Development (IAASTD) also stressed the multifunctional role of agriculture and the centrality of small and medium-sized farms applying agro-ecological farming methods to reducing environmental degradation, global warming, poverty, and social inequality [31].

Apart from the tension with capitalist agro-food corporations, the concept of food sovereignty and the local food movement are being critically observed and contested in various ways. Food sovereignty as a political project, for example, is often associated with social movements in the Global South. It is not clear how well it applies to places in the European Community or North America. Most recently, food sovereignty has been critically discussed as a theoretical concept that aims at integrating sometimes competing claims, such as family farming and gender equality [32]. Furthermore, researchers argue that the terms "local", "alternative", "regional", "speciality", or "sustainable" should not be used interchangeably as local speciality and niche market food products are often colonized by the conventional food system and thus might not foster food sovereignty. Rather, they suggest that other aspects of local food economies should be explored. For example, the "public procurement of local foods and cooperative/community food schemes offer much greater potential for the development of food supply systems that are more economically, socially and environmentally sustainable” ([33], p. 343). Others advise against the so-called "local trap", arguing that "local-scale food systems are equally likely to be just or unjust, sustainable or unsustainable, secure or insecure. No matter what its scale, the outcomes produced by a food system are contextual: they depend on the actors and agendas that are empowered by the particular social relations in a given food system" ([34], pp. 195,196). Others introduce the term "Ecology of Scale", arguing that, compared to bigger production units, small farms need more energy to produce and distribute their produce because they are not able to invest in energy saving and recovery technologies. That is to say, business size, rather than the question of whether food is produced and distributed locally, determines energy turn-over [35]. Furthermore, some have asked whether local organic food supply has the potential to be up-scaled to provide food for cities, nations, or even the world [19,36]. However, local food networks are already facing their own challenges. They are struggling to organize themselves in ways that are sustainable, allow for strong civil engagement, and which avoid assimilation into the dominant global food system. 
A huge variety of local food networks are emerging in Europe and across the globe [37-39]. On- or off-farm direct sales by individuals are the simplest form of local food supply. One may further find so-called grass-roots cooperatives set up by farmers [40-42], which are often very basic arrangements where, for example, one farmer takes the products of other farmers to the market and sells them without a surcharge. The incentive in this case is that the farmer's products become more attractive through availability amongst a wider range of high quality products. Another example is the use of a shared label to make it easier for consumers to recognize local farmers and their quality standards. Such labels frequently share logistics and supply chains to reduce marketing costs for the farmers involved. Other examples of local food networks are so-called civic or alternative food networks [37,38]. Most often, these are initiated by consumers trying to set up a closer relationship between themselves and producers. There are different types of such initiatives. Some take the form of Food Coops or solidarity purchasing groups, collectively purchasing direct from the farmers. Other initiatives, such as Community Supported Agriculture (CSA), are characterized by a strong and long-lasting economic partnership between consumers and producers accompanied by a certain de-commodification of food, that is, producing food for people and not for profit [43-45]. In urban areas in particular one finds community and guerrilla gardening as well as Veggie Box Schemes.

Many of these local food networks adopt the concept of food sovereignty as a kind of "leitmotif" and try to comply with its basic principles. This opens up a number of challenges regarding the socio-economic and bio-physical performance of local food networks. In this paper we shed light on how the Austrian local food network "SpeiseLokal" addresses the challenge of putting the concept of food sovereignty into practice. We demonstrate how the producers, distributors, and consumers involved attempt to realize more ecologically sound modes of production, distribution, and consumption and how they try to set up more equitable socio-economic relationships that allow for a safe and sustainable livelihood for all involved. We depict the critical points that either strengthen or constrain local food networks from operating, up-scaling, and getting organized in the ways they wish; that is, according to the principles and aims of food sovereignty and without assimilating into the dominant food regime. This paper should thereby help in finding measures that would encourage local food networks and a transition towards food sovereignty.

\section{Methodology}

Data were collected by means of qualitative interviews [46] with producers, consumers and retailers involved in SpeiseLokal and other Austrian local food networks. Of these networks, two of them are organized in a similar way to SpeiseLokal, one is a Community Supported Farm and one an urban FoodCoop. Participant observation [47] was done during SpeiseLokal's retailing activities and staff-meetings as well as at international meetings such as the first European Forum on Food Sovereignty in Krems, Austria (August 2011), the Food Revolt Conference in Burntisland, Scotland (November 2011), and the European Meeting on Community Supported Agriculture in Milan, Italy (October 2012). We took an inter- and trans-disciplinary approach [48] in which research questions and design were formulated and results critically reflected upon in conjunction with SpeiseLokal and the people involved with it. Presenting a case study as we do here, with all the detail it provides, partly stems from this trans-disciplinary approach. While working closely with stakeholders it became 
evident that a reflexive, in-depth analysis of everyday experiences that sheds light on the links between social practices and systemic constraints was highly desirable. In such manner, the case study (while also representing a unique case) exemplifies many of the often abstractly described challenges and constraints local food networks are facing in their endeavours to foster a transition of the current food system. In the following discussion we start by introducing the Multi-Level Perspective (MLP) (see for example [49]) which serves as an analytical framework, conceptualizing SpeiseLokal as a niche-innovation. We then describe SpeiseLokal in more detail and explore the main actors' (producers, consumers, and retailers) practices according to three analytical dimensions: the economic, the social, and the biophysical. We finally shed light on the critical points of intersection between SpeiseLokal and the dominant food regime and try to touch on the constraining and challenging character of the socio-economic landscape in order to explore what makes SpeiseLokal and other local food networks struggle to induce and advance a transition towards food sovereignty.

\section{Drawing on Transition Theory-the Multi-Level Perspective}

Local food networks such as SpeiseLokal fit well the concept of niche-innovation as introduced by transition theories such as the MLP [50]. Such networks can be conceptualized as grassroots activities that incorporate civil society as a major agent of change, creating a space for developing and expressing new ideas and practices and for experimenting with new systems of food-provision explicitly aimed at regime transitions [51,52]. As such, they represent good case-studies with which "to respond to one of the most significant research questions raised by transition theories: to what extent, and in what conditions, can niches significantly impact on regime change?" ([50], p. 29).

According to MLP, transitions are regarded "as non-linear processes that result from the interplay of developments at three analytical levels" ([49], p. 26): niches, socio-technical regimes, and an exogenous socio-technical landscape. Niches are the locus for radical innovations, that is, places or "incubation rooms" where novelties emerge widely protected against dominant regime-dynamics. The rules, values, and structures of niche-innovations are unstable and "in the making". Socio-technical regimes form the locus of the established, stable and well-articulated practices and associated rules and structures that stabilize existing systems. They are defined as "those organisations that, in the aggregate, constitute a recognized area of institutional life; key suppliers, resources and product consumers, regulatory agencies, and other organizations that produce similar services or products. The virtue of this unit of analysis is that it directs our attention not simply to competing firms ... or to networks of organizations that actually interact... but to the totality of relevant actors" ([53], p. 148), (cited in [54], p. 402). Socio-technical regimes refer to and illuminate the technical and bio-physical (e.g., climate or soil fertility) as well as the socio-economic (e.g., political ideologies, societal values, or macro-economic structures) backdrop that sustains society. A transition is said to take place when there is a fundamental shift of the dominant regime; that is, when major practices and the dominant rules and structures of society have changed. Niche- and regime-actors cannot fundamentally alter the exogenous socio-technical landscape in the short term; change requires the mobilization of different community actors and takes time. [49].

From a food regime perspective specific (agricultural) policies and the liberalization of global food and agricultural markets have created a food regime that is dominated by transnational food-corporations 
and based on industrialized large-scale agriculture and food distribution [55]. This food system is highly interwoven with the global financial and energy regime. It is thus subject to various external landscape pressures such as volatile energy prices, global financial instability, poverty, social inequality, hunger, malnutrition, resource degradation, and climate change; pressures which are partly induced and reproduced by the food regime itself. Farmers, processors and distributors experience these pressures in that they are forced to either give up their occupation or to take on high loans that allow them to up-scale and intensify their productivity [56]. Consumers, on the other hand, find themselves buying highly processed, unhealthy food. In order to escape these dynamics producers, processors, distributors and consumers have established niche innovations such as local food networks.

Local food networks initially form and develop in local niches within a given food regime. They induce socio-ecological changes on the local level and as they become more clustered and abundant they have the potential to foster wider transformations of the dominant food regime. Local food networks are characterized by specific practices, technologies, and actors analytically situated outside or peripheral to the dominant food regime, creating their own inherent structures and rules. Nonetheless, niche-innovations do not develop and evolve isolated from and untouched by the regime's and landscape's dominant practices, technologies, rules, and structures. Rather, socio-technical regimes, landscapes and niche-innovations can be seen as co-evolving and potentially competing or even colliding into one another [57]. Further, transition pathways differ depending on socio-economic preconditions, historical conjuncture, and the specific relationships existing between niche-innovations, regimes, and landscapes [54]. This implies that a significant rise in the abundance of niches usually builds on specific regime and landscape preconditions and the relationship between them both. The distribution of power is central in this regard: if powerful actors do not identify or experience major landscape or regime problems they will keep on reproducing the underlying regime structures or merely plead for minor changes that do not affect the regime's inherent dynamics (an example would be the "greening" of food production via the introduction of new "green" technologies which do not structurally challenge the dominant power-relations). Identifying the critical points of intersection, that is the points where niche-innovations, regimes and landscape "collide" or contradictions occur uncovers possible points of intervention that potentially foster socio-technical transitions.

\section{The Case Study "SpeiseLokal"}

SpeiseLokal is an Austrian local food hub that has emerged only recently. It is situated in Maria Anzbach, a rural community $30 \mathrm{~km}$ west of Vienna and $20 \mathrm{~km}$ east of St. Pölten, the capital of the province of Lower Austria. Maria Anzbach and its surrounding communities have good public transport connections to Vienna and St. Pölten. The communities are characterized by a high rate of incoming migration and by a high number of "green voters" (around 15\%). One specific characteristic of the area is the high number of civic initiatives, such as parent-organized kindergartens and schools and the wide variety of alternative cultural and educational offerings. Although Maria Anzbach is a rural area populated with active (organic) farmers, it has until recently required a great deal of time and effort to buy local organic food. There was no single shopping location providing a wide organic and local range of products. 
Given these conditions, SpeiseLokal started life as a consumer-driven initiative in conjunction with a female organic farmer. It was originally conceived of as a platform for connecting people interested in local food. It aimed to provide information on local and global food systems and various aspects of food, nutrition, and gardening. Very soon, the idea arose of creating conditions for the purchase of local organic food. From the beginning the people involved had families and were already active in other civic initiatives (e.g., parent-organized kindergartens and schools). Thus the idea of setting up a Food Coop in the classical sense, involving a rather high amount of voluntary work, seemed neither attractive nor feasible. Furthermore, the idea of setting up a CSA (Community Supported Agriculture) seemed also to involve too much voluntary work and there was no farmer interest in such a project [58]. Moreover, it was important for those involved that the initiative did not remain exclusive and only attracts a small number of people already interested in a local organic diet. The aim was to provide local organic food for everyone.

Inspired and encouraged by other Austrian local food networks, three women set about tackling this task. They visited about 40 farmers, between 0 and $80 \mathrm{~km}$ from Maria Anzbach, and asked whether they would be prepared to deliver them pre-ordered products once a week. This was done in cooperation with two women who had started a similar civic food network in St. Pölten. The intention was to set up a solidarity-based small enterprise that would sell organic food produced by local farmers. "Solidarity-based" for SpeiseLokal meant fair prices and close, equitable relationships between consumers, producers, and retailers. As most of the farmers agreed to deliver their products, SpeiseLokal soon started to sell once a week. Consumers made orders between Friday noon and Tuesday morning via a web shop. The farmers received these orders by Tuesday afternoon and delivered on Thursday or Friday morning. On Friday consumers picked up their orders at the farmers' store, rented on a farm by SpeiseLokal.

SpeiseLokal continues to foster close relationships between farmers, consumers, and retailers by serving as a platform for connecting people and initiatives. It arranges excursions to the farmers who deliver to it. It organizes, coordinates and promotes cookery workshops, lectures, seminars, dinners, and other events related to food. It provides information on food production, distribution, and consumption, helps people share their ideas, recipes and initiatives and constantly reaches out to other local actors such as politicians, members of the local gastronomy, and other local retailers and associations.

At the moment, SpeiseLokal is organized by five women, who get paid regularly for their retailing work and for organizing events and excursions. The women have different educational backgrounds. Three of them are academics, one is a farmer, and one is a teacher. They are between 40 and 50 years old and live with their families. A couple of other women provide help when needed. They work on specific tasks such as website-design and maintenance, public relations, and graphics and design.

About 35 farmers are actively involved with SpeiseLokal. They deliver raw products such as grain, seeds, milk, vegetables and fruits as well as processed food such as flour, bread, oil, cheese and other dairy products, cereal-products, wine, juices, and pickles. Some farmers deliver their products themselves, some in cooperation with other farmers and some via an alternative retailer. The farms are family-run and very few employ seasonal staff. About 10 small (1-20 employees) food-processing companies, e.g., a bakery, an apiarist, and a cheese maker, are also involved.

About 70 households out of the 300 who are in contact with SpeiseLokal order weekly. The size of households varies from single-person households, to couples and families with three to seven 
members. Customers' ages range from between 20 and 80 years, although the majority seem to be between 30 and 50 years old. They come from different social backgrounds and include workers, farmers, and academics.

\subsection{Economic Aspects of SpeiseLokal's Practices}

In general producers get higher prices from initiatives such as SpeiseLokal than they would from supermarkets and wholesale traders. Thus SpeiseLokal offers additional income to producers. For some producers (of vegetables, dairy products, and meat) this additional income might become primary if demand from SpeiseLokal grows. In particular, producers who predominantly sell directly themselves and/or who deliver mainly to small retailers appreciate the additional income that comes without extra expenditure or workload. However, those producers who predominantly sell raw products to wholesale traders find delivering to SpeiseLokal requires a high workload to process and package small amounts of food. As labor on farms is scarce and expensive, these farmers deliver to SpeiseLokal for ideological reasons rather than principally for economic benefit. For those producers who sell raw products (e.g., cereals, fruits) to supermarkets and wholesale traders as well as to small retailers, delivering to SpeiseLokal usually results in, neither a significantly higher workload, nor a significant rise in income. This group of producers also cooperates with SpeiseLokal mainly for ideological reasons as they wish to support local food supply and food diversity. Many farmers have had bad experiences with wholesale traders who have ordered huge amounts of produce, which they then did not purchase. Thus, producers specifically appreciate that they decide in cooperation with SpeiseLokal what to sell and when, how much and at what price. For some farmers involvement in SpeiseLokal has made it possible to produce and sell products, which they would have liked but have been unable to produce before. That is to say that producers have gained a greater amount of choice and sovereignty in their decision-making processes: it is they who have decided, through dialogue with consumers and retailers, what to produce, rather than being dictated to by an anonymous market that primarily aims at making profit from one's own produce.

What can be seen here is that niche-innovations such as Speiselokal are starting to form structures that lead in the direction of food sovereignty as they offer a decent income for farmers, more flexibility and sovereignty in decision-making processes as well as relationships that feel more equitable. Farmers gain control of what they produce: they decide what production methods to use, how much to produce, and for whom. Food is produced for consumers; it is eaten and not left on shelves to be litter afterwards.

Nevertheless, there are various critical intersections between local food networks and the dominant food regime and the wider economic landscape. Thus, while better prices and closer relationships with consumers do ameliorate conditions for farmers, producers still require sufficient outlets for their produce, be they small and regional or large and global. Given the dynamics of the dominant food regime with its volatile energy, land, and food prices, low agricultural wages and high labor taxation, high amounts of produce have to be sold in order for farmers to gain sufficient income to cover labor-costs and necessary investments. Farmers respond to the treadmill of producing ever greater quantities food for lower prices by supplying multiple local food hubs or by employing hybrid strategies [59,60] selling to both small, local retailers, and wholesale traders. Some diversify in the sense that a livestock 
breeder, for example, might start to grow vegetables. This almost inevitably entails an increase in workload, which some farmers try to spread among themselves and the people they work with. It is obvious that in order to avoid (self-)exploitation, cooperation as that which exists, for example, between members of local food networks (producers, processors, distributors, and consumers) is essential. However, not all small farms manage to sustain, organize, and finance an increase in workload which is why local food networks constantly have to work on having enough farmers able to provide enough food(-diversity). Moreover, few farmers dare to take different pathways, radically altering their economic performance. As for SpeiseLokal, only one farm has attempted to do so. Blighted by excessive labor with working hours from two a.m. until dusk during high season, this farm has set up a community-supported farm in co-operation with SpeiseLokal and other local food networks. In this case, the yearly budget of the farm is pre-financed by consumers who in turn get weekly vegetable supplies.

The volatility of food-, energy- and land-prices makes farmers, processors as well as distributors and consumers try to avoid long transport routes and cooling chains. Here again co-operation occurs with producers sharing transport routes and cooling facilities. In a few cases local currencies are being introduced, which aim at avoiding price volatility. In order to avoid high economic costs and dependency on big corporations, farmers have tried to set up closed system cycles that allow them to use their own seeds and organic fertilizers. They have also tried to establish systems of sharing land and infrastructure. They cooperate, for example, in sharing seeds. Furthermore, farms with livestock might provide fertilizers to farms without livestock.

Those consumers who mainly shop for food at SpeiseLokal and other local food suppliers have found that they spend roughly the same amount of money on food as they did before, and in some cases less (even though they had assumed that they would in fact spend more). The reason for this, they argue, is that they only buy things they really need and they eat everything they buy. Furthermore, the need to order in advance forces them to plan their weekly diet. Consumers found that the more they got used to this planning process the more they discovered what they really needed to buy, helping them to calculate and monitor their food needs and related expenditure. Further, consumers appreciate not being dictated to by an anonymous market and prefer being provisioned directly by the farmers themselves.

Consumers who still do their main food-shopping at supermarkets and buy some "extras" at SpeiseLokal usually find that they spend more money on food than they did before. However, their expenditure depends to a large extent on the type of produce they purchase at SpeiseLokal. Meat and dairy products tend to be more expensive than in supermarkets. Yet, those consumers who mainly buy seasonal vegetables and grains do not notice a rise in food expenditure. The same applies to consumers who buy around $50 \%$ of their food at SpeiseLokal.

There is no clear evidence that spending more money on food causes consumers to spend less money on other items or activities (holidays, clothes, etc.). As families with both a low and high family budget buy their basic foodstuffs at SpeiseLokal, it is likely that it is not only their overall economic situation that dominates their purchasing behavior, but rather the importance of food issues to the family. This might indicate that Speiselokal makes local food accessible for low- as well as for high-income households, potentially bridging the class-divide in access to food. Nevertheless, SpeiseLokal does not reach the "average" consumer. Rather, it attracts people with a high educational 
background or those already concerned with "alternative" lifestyles. In this regard SpeiseLokal fails in achieving the aim of food sovereignty, that is, in providing healthy and sustainable food for everyone. The reasons for this are various, and include the lack of (agricultural) education among consumers and the dominance of food-corporations in the current food regime.

The retailing and educational activities of SpeiseLokal are funded by a surcharge on the produce that is sold. This means that the closer social ties between farmers, retailers and consumers are still rooted in commodity relations. "De-commodification" only takes place in the sense that food is not primarily used as a commodity for making profit. Rather, food is pre-ordered from people and delivered for people, and farmers and traders aim to get paid for their work, not for profit maximization. That is to say the attempt to construct an alternative to the structure of the dominant food regime that complies with food sovereignty is partly realized. Nonetheless, SpeiseLokal's retailing duties remain trapped in the tension between the dominant market-economy and niche-economy dynamics. This is evidenced by the fact that wages at SpeiseLokal are low and none of the people involved can make a living from them. As with the farmers, higher amounts of produce would have to be sold or labor-taxes would have to be reduced in order to pay higher wages. Therefore at the moment income from SpeiseLokal is only regarded as "extra money" that retailers and their families receive, combined with affordable and healthy food. This indicates that SpeiseLokal's retailing-duties are currently forced to stay a niche activity as only people who are able or willing to afford low incomes are involved. SpeiseLokal has, thus, been thinking of setting up a community-supported retailing system in order to avoid being trapped in market-economy dynamics. However, this would require a great amount of work and the involvement of highly motivated consumers and farmers. It would further reduce the array of products being sold.

Legal obstacles and the hygiene regulations of the current food regime also force retailers to perform in specific market-conforming ways. This means that SpeiseLokal cannot officially establish trade-relations with farmers who are not able to comply with the hygiene or declaration standards needed for retail. As an example, eggs and chickens are difficult to source locally as farmers would have to invest in slaughtering and packaging facilities or in expensive equipment for marking the eggs. This mirrors the fact that Speiselokal, as a niche-innovation, struggles with the legal structures and infrastructures provided by the dominant food regime that mainly supports retailing on a larger, often global scale.

\subsection{Social Aspects of SpeiseLokal's Practices}

Farmers, in general, experience a higher workload than they have in delivering to wholesale traders. In particular farmers who process raw products find delivering to SpeiseLokal or to other local food networks requires extra work (mainly in terms of packaging and transportation) for low returns, as they only deliver small amounts of produce. As mentioned above, to reduce the time spent on transportation, many farmers collaborate and make collective deliveries to SpeiseLokal. While direct selling and delivery to small retailers involves a high workload, the cooperation among farmers and between farmers, retailers, and consumers is often experienced as a gain in the farmer's quality of life. This indicates that obstacles set by the given food regime and the economic landscape, such as high labor costs and low agricultural wages, are balanced by relations of regard and cooperation. There remains a danger, however, of labor-exploitation hindering a significant dissemination of local food 
networks. Furthermore, farmers are not trained in setting up new forms of relationships as the current food regime and its educational system focuses on growth and cooperation with food-corporations rather than on cooperation between (small) farms themselves and between farmers and consumers.

Farmers gain the satisfaction of a more direct relationship with local customers. They see the products of their hard labor being valued by local consumers and appreciate their flexibility in regard to seasonal produce. Farmers and consumers value the opportunities SpeiseLokal's networking affords. Information about producers and farming is made available via the shop, a website, and via dedicated events, making producers more approachable to consumers. Producers gain publicity, direct communication with customers, and new selling opportunities. However, the intensity of economic and social ties between producers, consumers, and retailers differs greatly. Critical factors in this regard are the constraints of time, the quantity of produce that is sold and how frequently produce is delivered. Furthermore, the wide variety of products sold by SpeiseLokal mitigates against the establishment of strong relationships with all the farmers involved. A smaller array of products would allow for closer ties but would also require new economic relationships of the kind seen within community-supported agriculture. That is to say complying with the requirements of the dominant food regime, such as offering a large array of products, mitigates close social ties between producers, retailers, and consumers, but does not completely prohibit them.

Those consumers who purchase their basic food stuffs at SpeiseLokal find that they spend less time on purchasing food than before. Furthermore, purchasing food at SpeiseLokal is not experienced as "shopping". Rather it is more about "picking up the stuff you need and getting in touch with people". Thus, for those consumers who hardly go to supermarkets or do not enjoy shopping in supermarkets, the time spent in buying food has changed both qualitatively and quantitatively. However, the way of purchasing at SpeiseLokal, that is by pre-planning, advance-ordering, adhering to deadlines and organizing collection, challenges many consumers to change their routines around food shopping. Not every motivated consumer successfully manages these changes as supermarkets are present everywhere offering a variety of organic products throughout the whole year. Currently only a small group of consumers is able and willing to see and value the benefits local food networks provide. People with low education or little affiliation to "alternative" lifestyles are unlikely to be attracted by SpeiseLokal's activities or to get in touch with it.

People often change their diet and their habits of preparing food after joining SpeiseLokal. Cooking, they say, becomes a challenge, a "creative process" as consumers are encouraged to use fresh and seasonal ingredients only available at certain times of the year. People increasingly avoid fast food and become less reliant on processed foods: for example, some consumers have started making their own dough and purchasing new cooking implements so as to be able to mill poppy seeds and cereals themselves. Preparing fresh food is experienced as "a gift to oneself and one's family". Eating local produce involves an increase in food diversity for most consumers as they eat things they had not known before. Due to their socialization with convenience foods and the ready availability of a wide range of processed and packaged food, many consumers initially struggle with cooking and storage. It requires education to adapt to a new lifestyle and it also requires support such as, for example, providing recipes, cookery workshops, or shared storage-facilities. As spending more time cooking may compete with other activities such as work or leisure time activities, a local diet requires both the opportunity and willingness to change time-use patterns. Due to regime restrictions (e.g., working 
contracts) shorter working hours are hard to achieve for many people and would often imply financial challenges and fundamental changes in life-style.

As people find that certain kinds of vegetables, fruits, or cheese are not available throughout the whole year, food becomes more valued and thus less likely to be wasted than before. Some consumers have started to process and preserve food for use at times of limited food variety. It is now nature and not the supermarkets, they argue, that dominates their food consumption. A number of consumers now spend more time growing their own food. One group of people, for example, has started community gardening. Others have begun keeping chickens. Nevertheless, knowledge of farming, processing, and storing food would have to be provided to enable people to understand and accept why and when the variety and quality of produce changes. Furthermore, providing a seasonal diet in school kitchens and other public institutions would help in this regard.

An important factor for consumers is trust. Many are confused due to a surfeit of information and misinformation about food, nutrition, economic, and environmental issues. Organic, as a quality standard, is in question. Shopping at SpeiseLokal seems to offer consumers the feeling that they are "doing the right thing" without having to engage with all the details.

As mentioned above, the money retailers earn at SpeiseLokal is regarded as "extra money" that they and their families receive together with affordable and healthy food. However, retailing also means additional work that has to be done in addition to one's own occupation and family responsibilities. Thus, for most retailers, the extra work presents a challenge to their work-life balance. The main concern is whether this increased workload will lead to the exploitation of retailers. Furthermore, the limited availability of time combined with restricted financial resources make it difficult for retailers to keep close contact with all the farmers involved. Limited resources also hamper SpeiseLokal's efforts to reach out to other local actors and associations to make people aware of the social and environmental implications of the given food regime.

At the moment the women who perform retailing duties at SpeiseLokal are idealistically motivated. They appreciate the healthy and fresh food made available, the contact with the farmers, the reflexive teamwork and the high degree of self-determination their involvement with SpeiseLokal brings. They try to be flexible and to take into account personal interests, preferences, and skills, as well as differing individual working speeds and rhythms. This approach to time and team work is critical to avoiding an unduly high work load for any individual team member and ensuring a relatively relaxed and happy working atmosphere. However, it stands in contradiction to the working structures and values of the given socio-economic landscape that steadily trap people on the treadmill of working more and more hours. One could argue that off-setting these socio-economic pressures requires a number of personal preconditions for local retailers, such as having additional sources of income, a high degree of ideological motivation and flexible work and family structures.

\subsection{Ecological Aspects of SpeiseLokal's Practices}

What is evident is that SpeiseLokal produces very little food waste. This is due to the fact that farmers only provide the amount of food that is actually needed (i.e., ordered) and consumers say that they usually eat all that they buy. There are no data available on food losses related to production processes and the storing of food on the farms. However, most of the food is stored only for a short 
space of time as fresh produce (e.g., bread, meat, dairy products, vegetables, and fruits) is usually sold immediately after production.

Transport-routes are generally short (between 0 and $100 \mathrm{~km}$ ) and farmers as well as consumers cooperate by regularly transporting food for others. Nevertheless, people regard the location of the shop (on top of a small hill, outside the village) as disadvantageous in terms of fuel-expenditure and approachability. Furthermore, due to the missing infrastructure, such as local mills, oil presses, creameries, or slaughtering facilities, a number of products necessitate high transport-miles. In this regard, local food networks are hampered by the boundaries set by the dominant food regime. For example, most small mills have been closed down and small farms are forced to collaborate with bigger mills. It is, however, most often difficult for small farms to find a nearby big mill that is willing to peal small amounts of grain and seeds. This applies specifically to grain that is hard to clean and peal, such as buckwheat or millet, as well as to laborious cereal-produce, such as millet-flakes or small oat-flakes. Oat-flakes at SpeiseLokal, for example, come from a local farmer who delivers his oats to a mill situated in another Austrian province. The cleaned oats are brought to Germany where they are transformed into oat-flakes. The oat-flakes are then brought back to the mill where they are picked up by the farmer and finally delivered to SpeiseLokal. Another example for the lack of small-scale, local infrastructure is the scarcity of on-farm slaughtering facilities (which small farms can hardly afford) and the prohibition of slaughter on pastures. These examples illustrate that in many cases the given food regime makes local, small scale food supply and processing impossible, unless farmers (and consumers) collaborate intensively and invest in common infrastructure.

The amount of packaging used by SpeiseLokal is low. In particular the use of milk bottles and the absence of packaging or, where it is used, its recycling for fruit, cereals, vegetables and eggs, make most consumers experience a significant drop in household waste.

SpeiseLokal appears to result in changes in consumption patterns as some consumers clearly modify their diet and manner of cooking and of purchasing food. Members tend to eat more seasonal vegetables as that is all that is available through SpeiseLokal. They also eat less meat or consume different cuts of meat (the cheaper parts) as meat is rather expensive. The resulting seasonal, low-meat diet and fresh cooking is usually regarded as less resource intensive and healthier than a non-seasonal diet involving the consumption of ready-made meals. Unfortunately, general data on this topic are rare [61].

Food is grown organically on small-scale farms with a rather closed substance cycle and none of the products are processed industrially. However, quantitative analysis would be required in order to measure the energy and resource use of specific organic production methods as well as of artisanal production. Furthermore, dealing with the resource use of specific products sold by SpeiseLokal would require quantitative assessment of various products such as a life cycle analysis or food miles [62,63]. Such studies would on the one hand help to evaluate different production methods in terms of their environmental impact. They would further help to depict the limits and challenges of producing enough food on the local level. Thus far, we have focused on the socio-economically induced limits set by the food regime and the socio-economic landscape (e.g., high labor costs, the price of energy and other resources, missing infrastructure). However, it is also essential to capture the restrictions and impact of the biophysical landscape, such as climate change, the availability of arable land, and soil fertility - a complex undertaking that goes beyond the scope of this paper. 


\section{Conclusions}

The findings of this paper have uncovered a number of critical points of intersection between local food networks as niche-innovations, the dominant food regime and the wider socio-economic landscape. These intersections impact negatively on local food networks, making them struggle to perform in accordance with the principles and aims of food sovereignty. They also prevent them from becoming abundant enough to disseminate into or even displace the dominant food regime. (i) Local food networks have no direct influence on the landscape-induced and regime-inherent high labor costs and the volatility of food-, energy- and land- prices. Thus, given their labor- and land-intensive production, processing, and distribution methods, local food networks are hardly able to up-scale. (ii) Local food networks are constantly confronted with regime-inherent and landscape-induced market dynamics and legal structures. That is to say, farmers and retailers who join local food networks are forced to sell high amounts of produce if they are unable to diversify or collaborate with other farmers. In addition, legal obstacles and hygiene regulations mainly support large-scale retailing and farming and force local retailers and farmers to perform in specific market-conforming ways. (iii) The current food regime does not train farmers in how to set up new forms of relationships and collaboration with each other and consumers, but rather encourages growth, competition, and the subjugation to and cooperation with food-corporations. Farmers are thus discouraged from joining local food networks and from realizing alternatives to existing market-relations. Furthermore, farmers are not usually trained in organic production methods as traditional agricultural education focuses on conventional farming methods. This decreases farmers' trust in the viability of non-conventional farming practices. (iv) The current food regime augments infrastructure, technologies and research that facilitate resource-intensive production methods and large-scale production, processing, and distribution. Small-scale infrastructure is increasingly squeezed and research and new technologies that serve the needs of small-scale production and processing are rare and underfunded. This hinders local production and the processing of certain produce. It further leaves open the question of how local food supply can cope with the impact of the biophysical landscape (e.g., climate, arable land, or soil fertility). (v) The missing (agricultural) education, the everyday presence and dominance of food-corporations and supermarkets and the dominant cooking and purchasing patterns make it difficult for local food networks to reach the "average" consumer, that is, to make healthy and sustainable food accessible to everyone. (vi) The dominant labor-structures, such as long working hours that the economic regime constantly reproduces make it difficult for people to comply with the aims and requirements of local food networks, namely the adoption of flexible and reflexive team work that helps avoid labor-exploitation.

The obstacles arising from the intersection of local food networks with the dominant food regime and economic landscape make it difficult for local food networks to develop the stable structures that would help them move beyond the niche level. This is reflected in the fact that personal engagement remains the backbone of local food networks. Fundamental structural changes at the regime and economic landscape level would be needed [64] in order to strengthen local food networks so as to allow them to induce a sustainable regime transition towards food sovereignty. Measures that would foster such structural changes would be the taxation of commodities rather than wages. Research, infrastructure, and hygiene regulations that serve the needs of small farms and retailers [65] would 
further be needed. Education curricula would have to be altered in order to increase civic knowledge of farming and the processing and storage of food, as well as to provide knowledge of organic and agro-ecological farming methods. Moreover, sharing knowledge and creating new forms of logistics that facilitate local food supply are essential to the long-term prospects of local food networks. People would need to become educated and encouraged to form networks involving farmers, retailers, consumers, and food processors. This does not entail promoting entrepreneurship by giving loans. Rather, information and scholarships could be provided to empower citizens to become actively involved in local food networks. Shorter working hours, local currencies, and an unconditional basic income [66] for citizens might be useful in this regard.

Nevertheless, our research shows that local food networks such as SpeiseLokal do in many ways induce discursive and behavioral changes at the micro level as they open up new (local) pathways for consumers, producers, and retailers to alter their patterns of production, retailing, and consumption, and how they interact with one another. By constantly reaching out to local actors who are not part of the local food network, SpeiseLokal helps make people aware of the social and environmental consequences of conventional food production and consumption. These changes in discourse and behavior serve the goals of food sovereignty in various ways: (i) by providing decent incomes that assure a safe and sustainable livelihood, local food networks support the peasantry and small scale farming and make them more economically resilient; (ii) by producing food primarily for people and not for an anonymous market, and by setting up equitable relations in which neither producers nor consumers nor retailers feel dominated or squeezed, local food networks contribute to creating a food system in which decisions and control-mechanisms are democratically organized and social equity becomes more likely; (iii) local food networks make healthy, ecologically sound and culturally diverse food available, though they are not at the moment accessible to everyone; and (iv) by promoting organic and similar production methods, and by avoiding food wastage, environmentally-unfriendly packaging, and long transport miles, local food networks help to ensure a healthy, regenerative, and resilient natural environment.

\section{Acknowledgments}

Co-funding from the ERC 263522 LUISE for writing this paper is gratefully acknowledged.

\section{Conflicts of Interest}

The authors declare no conflicts of interest.

\section{References and Notes}

1. Rosin, C.; Stock, P.; Campbell, H. Food Systems Failure: The Global Food Crisis and the Future of Agriculture; Earthscan: New York, NY, USA, 2012.

2. Ericksen, P.J. Conceptualizing food systems for global environmental change research. Global Environ. Change 2008, 18, 234-245.

3. Friedman, H. International political economy of food: A global crisis. New Left Rev. 1993, 197, 29-57. 
4. Exner, A.; Fleissner, P.; Kranzl, L.; Zittel, W. Kämpfe um Land. Gutes Leben im post-fossilen Zeitalter (in German); Mandelbaum: Wien, Austria, 2011.

5. Globalising Hunger: Food Security and the EU's Common Agricultural Policy (CAP). Available online: http://fdcl-berlin.de/fileadmin/fdcl/Publikationen/CAP/CAPpaperfinal-print.pdf (accessed on 29 August 2013).

6. Weingärtner, L.; Trentmann, C. Handbuch Welternährung; Campus: New York, NY, USA, 2011.

7. Patel, R. Stuffed and Starved: From Farm to Fork, the Hidden Battle for the World Food System; Portobello: London, UK, 2007.

8. Choplin, G.; Strickner, A.; Trouvé, A. Ernährungssouveränität: Für eine andere Agrar- und Lebensmittelpolitik in Europa (in German); Mandelbaum: Wien, Austria, 2001.

9. Friedman, H. From Colonialism to Green Capitalism: Social Movements and the Emergence of Food Regimes. In New Directions in the Sociology of International Development. Research in Rural Sociology and Development; Buttel, F.H., McMichael, P., Eds.; Elsevier: Amsterdam, The Netherlands, 2005; pp. 227-264.

10. Friedman, H. Moving food regimes forward: Reflections on symposium essays. Agric. Human Values 2009, 26, 335-344.

11. Patel, R. The Value of Nothing. Was Kostet Die Welt?; Riemann: München, Germany, 2010.

12. Duram, L. Good Growing: Why Organic Farming Works; University of Nebraska Press: Lincoln, NE, USA, 2005.

13. Löwenstein, F. Food Crash. Wir werden uns ökologisch ernähren oder gar nicht mehr (in German); Pattloch: Nördlingen, Germany, 2011.

14. Pimentel, D. Impacts of Organic Farming on the efficiency of Energy Use in Agriculture: State of Science Report. Available online: http:/www.organicvalley.coop/fileadmin/pdf/ENERGY_SSR.pdf (accessed on 29 August 2013).

15. Kratochvil, R.; Lindenthal, T.; Vogl, C. Prozessqualität im Wandel: Beobachtungen am Beispiel der Bio-Wertschöpfungskette in Österreich. In Ende der Nische, Beiträge zur 8 . Wissenschaftstagung Ökologischer Landbau (in German); Heß, J., Rahmann, S., Eds.; Kassel University Press GmbH: Kassel, Germany, 2005.

16. Bartel-Kratochvil, R.; Darnhofer, I.; Lindenthal, T. Konventionalisierung im Biolandbau: Gefahren und Auswege. Zoll+ 2009, 14, 37-40, (in German).

17. Groier, M.; Schermer, M. Bio-Landbau im internationalen Kontext. Zwischen Professionalisierung und Konventionalisierung; Forschungsbericht 55 (2) (in German); Bundeanstalt für Bergbauernfragen: Wien, Austria, 2005.

18. Arvay, C. Der große Bio Schmäh. Wie uns die Lebensmittelkonzerne an der Nase herumführen (in German); Oberreiter: Wien, Austria, 2012.

19. Erb, K.H.; Haberl, H.; Krausmann, F.; Lauk, C.; Plutzar, C.; Steinberger, J.; Müller, C.; Bondeau, A.; Waha, K.; Pollack, G. Eating the planet: Feeding and fuelling the world sustainably, fairly and humanely-a scoping study. Soc. Ecol. Work. Pap. 2009, 116, 1-132.

20. Friedman, H. After Midas's Feats: Alternative Food Regimes for the Future. In Food for the Future: Conditions, Contradictions of Sustainability; Allen, P., Ed.; Wiley: New York, NY, USA, 1993; pp. 213-233. 
21. La Trobe, H.; Acott, T.G. Localising the global food system. Int. J. Sustain. Dev. World 2011, 7, 309-320.

22. Pollan, M. Food Rules: An Eater's Manual; Penguin Press: New York, NY, USA, 2009.

23. Friedman, H. Reinhabiting Our Earthly Home: Ways to Reshape an Urban Food Shape. Available online: http://www.ssc.wisc.edu/ wright/ASA/Harriet\%20Friedman\%20--\%20real\% 20utopia\%20proposal\%20on\%20Food\%20\&\%20agriculture\%20-\%20July $15 \% 20$ draft.pdf (accessed on 29 August 2013).

24. Schermer, M. Lokale Bioprodukte als Chance für Regionalentwicklung? In Wie wir überleben!: Ernährung und Energie in Zeiten des Klimawandels (in German); Gruber, P., Ed.; Barbara Budrich: Leverkusen, Germany, 2010; pp. 143-159.

25. Campbell, H. Breaking new grounds in food regime theory: Corporate environmentalism, ecological feedbacks and the 'food from somewhere' regime? Agric. Human Values 2009, 26, 309-319.

26. Friedman, H.; McNair, A. Whose rules rule? Contested projects to certify 'Local Production for Distant Consumers'. J. Agrar. Change 2008, 8, 408-434.

27. Wittman, H.; Desmaries, A.A.; Wiebe, N. The Origins and Potentials of Food Sovereignty. In Food Sovereignty. Reconnecting Food Nature \& Community; Wittman, H., Desmarais, A.A., Wiebe, N., Eds.; Pambazuka Press: Oxford, UK, 2010; pp. 1-12.

28. Schäfer, M.; Kröger, M.; Wirz, A. Mit alten Werten die Zukunft gestalten. Eckpunkte für ein faires Miteinander entlang der Bio-Wertschöpfungskette (in German). Available online: http://orgprints.org/17275/1/17275-Bio-Fair-Broschuere_2010.pdf (accessed on 29 August 2013).

29. An Answer to the Global Food Crisis: Peasants and Small Farmers Can Feed the World. Available online: http://www.grassrootsonline.org/publications/fact-sheets-reports/ answer-global-food-crisis-peasants-and-small-farmers-can-feed-w (accessed on 29 August 2013).

30. Lawrence, G.; McMichael, P. The Question of Food Security. Int. J. Soc. Agric. Food 2012, 19, 135-142.

31. International Assessment of Agricultural Knowledge, Science and Technology for Development (IASSTD). Agriculture at a Crossroads: Executive Summary of the Synthesis Report; Island Press: Washington, DC, USA, 2009.

32. Food Sovereignty: A Critical Dialogue. Available online: http://www.yale.edu/agrarianstudies/ foodsovereignty/papers.html (accessed on 29 August 2013).

33. Ilbery, B.; Maye, D. Food supply chains and sustainability: Evidence from specialist food producers in the Scottish/English borders. Land Use Policy 2005, 22, 331-344.

34. Branden, B.; Purcell, M. Avoiding the local trap: Scale and food systems in planning research. J. Plan. Educ. Res. 2006, 26, 195-207.

35. Schlich, E.; Fleissner, U. The ecology of scale: Assessment of regional turn over and comparison with global food. Int. J. Life Cycle Ass. 2005, 10, 219-223.

36. Woodhouse, P. Beyond industrial agriculture? Some questions about farm size, productivity and sustainability. J. Agrar. Change 2010, 10, 437-453.

37. Renting, H.; Mardsen, T.K. Understanding alternative food networks: Exploring the role of short food supply chains in rural development. Environ. Plan. 2003, 35, 393-411. 
38. Renting, H.; Schermer, M.; Rossi, A. Building food democracy: Exploring civic food networks and newly emerging forms of food citizenship. Int. J. Soc. Agric. Food 2012, 19, 289-307.

39. European Union. Local Food and short supply chains - a publication from the European network for rural development. EU Rural Rev. 2012, 12, 1-67.

40. Karner, S. Local Food Systems in Europe. Available online: http://www.speiselokal.org/ pdf/faan_booklet.pdf (accsessed on 29 August 2013).

41. Schermer, M.; Hirschbichler, K.; Gleirscher, N. Encouraging Collective Farmers Marketing Initiatives. Available online: http://www.cofami.org/documents/WP3_Status_Quo_AT.pdf (accessed on 16 May 2012).

42. Schermer, M.; Renting, H.; Oostindie, H. Collective farmers' marketing initiatives in Europe: Diversity, contextuality and dynamics. Int. J. Soc. Agric. Food 2010, 18, 1-11.

43. Schlicht, S.; Volz, P.; Weckenbrock, P.; Le Gallic, T. Community Supported Agriculture: An overview of characteristics, diffusion and political interaction in France, Germany, Britain and Switzerland. Available online: http://www.agronauten.net/downloads/CSA\%20OVERVIEW\% 20FINAL.pdf (accessed on 30 October 2012).

44. Pilley, G. A Share in the Harvest- A Feasibility study for community supported agriculture. Available online: http://orgprints.org/9062/ (accessed on 29 August 2013).

45. Hinrichs, C. Embeddedness and local food systems: Notes on two types of direct agricultural market. J. Rural Stud. 2000, 16, 295-303.

46. Froschauer, U.; Lueger, M. Das Qualitative Interview: Zur Praxis Interpretativer Analyse Sozialer Systeme; WUV-UTB Verlag: Wien, Austria, 2003.

47. DeWalt, K.M.; DeWalt, B.R.; Wayland, C.B. Participant Observation. In Handbook of Methods in Cultural Anthropology; Russel, B., Ed.; AltaMira Press: Walnut Creek, CA, USA, 1998; pp. 259-299.

48. Ukowitz, M. Wenn Forschung Wissenschaft und Praxis zu Wort kommen last ... Transdisziplinarität aus der Perspektive der Interventionsforschung (in German); Metropolis-Verlag: Marburg, Germany, 2012.

49. Geels, F.W. The multi-level perspective on sustainability transitions: Responses to seven criticisms. Environ. Innov. Soc. Transit. 2011, 1, 24-40.

50. Brunori, G.; Rossi, A.; Malandrin, V. Co-producing transition: Innovation processes in farms Adhering to Solidarity-based Purchase Groups (GAS) in Tuscany, Italy. Int. J. Soc. Agric. Food 2010, 18, 28-53.

51. Seyfang, G.; Smith, A. Grassroots innovations for sustainable development: Towards a new research and policy agenda. Environ. Polit. 2007, 16, 584-602.

52. Seyfang, G.; Haxeltine, A. Growing grassroots innovations: Exploring the role of community based initiatives in governing sustainable energy transitions. Gov. Policy 2012, 30, 381-400.

53. Di Maggio, P.J.; Powell, W.W. The iron cage revisited: Institutional isomorphism and collective rationality in organizational fields. Am. Soc. Rev. 1983, 48, 147-160.

54. Geels, F.W.; Schot, J. Typology of sociotechnical transition pathways. Res. Policy 2007, 36, 399-417. 
55. McMichael, P. Global Development and the Corporate Food Regime. In New Directions in the Sociology of Global Development; Buttel, F.H., McMichael, P., Eds.; Elsevier Press: Oxford, UK, 2005.

56. Van der Ploeg, J.D. The food crisis, industrialized farming and the imperial regime. J. Agrar. Change 2010, 10, 98-106.

57. Hargreaves, T.; Longhurst, N.; Seyfang, G. Up, down, round and round: Connecting regimes and practices in innovation for sustainability. Environ. Plan. 2013, 45, 402-420.

58. This has changed over time. One farmer who has been delivering to SpeiseLokal for 1.5 years will start a CSA in April 2013 - in co-operation with SpeiseLokal and other local food networks.

59. Jarosz, L. The city in the country: Growing alternative food networks in metropolitan areas. J. Rural Stud. 2008, 24, 231-244.

60. Mount, P. Growing local food: Scale and local food systems governance. Agric. Human Values 2012, 29, 107-121.

61. Foster, C.; Green, K.; Bleda, M.; Dewick, P.; Evans, B.; Flynn, A.; Mylan, J. Environmental Impacts of Food Production and Consumption: A Report to the Department for Environment, Food and Rural Affairs by Manchester Business School; Defra: London, UK, 2006.

62. Theurl, M. $\mathrm{CO}_{2}$-Bilanz der Tomatenproduktion: Analyse acht verschiedener Produktionssysteme in Österreich, Spanien und Italien. Soc. Ecol. Work. Pap. 2008, 110, 1-101, (in German).

63. Duram, L.; Oberholtzer, L. A geographic approach to place and natural resource use in local systems. Renew. Agric. Food Syst. 2010, 25, 99-108.

64. Gimenez, E.H.; Shattuck, A. Food crises, food regimes and food movements: Rumblings of reform or tides of transformation? J. Peasant Stud. 2011, 38, 109-144.

65. Mardsen, T.; Banks, J.; Renting, H.; van der Ploeg, J.D. The road towards sustainable rural development: Issues of theory, policy and research practice. J. Environ. Policy Plan. 2001, 3, 75-83.

66. Reitter, K. Bedingungsloses Grundeinkommen (in German); Mandelbaum: Wien, Austria, 2012.

(C) 2013 by the authors; licensee MDPI, Basel, Switzerland. This article is an open access article distributed under the terms and conditions of the Creative Commons Attribution license (http://creativecommons.org/licenses/by/3.0/). 